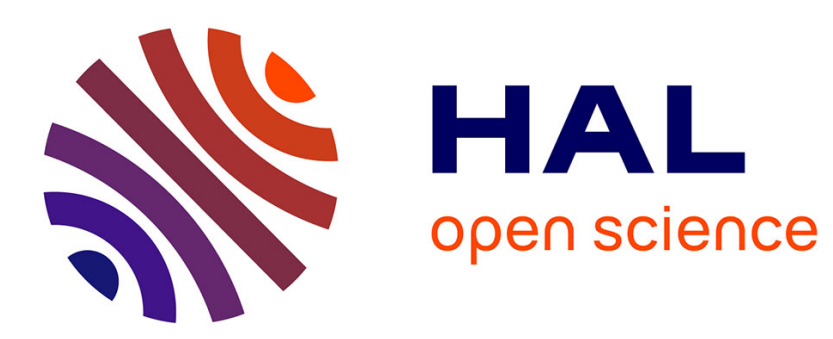

\title{
Effects of ruminally infused niacin on digestibility and rumen fermentation in the cow
}

\author{
Jf Ottou, M Doreau
}

\section{To cite this version:}

Jf Ottou, M Doreau. Effects of ruminally infused niacin on digestibility and rumen fermentation in the cow. Annales de zootechnie, 1994, 43 (Suppl1), pp.30s-30s. hal-00889097

\section{HAL Id: hal-00889097 https://hal.science/hal-00889097}

Submitted on 1 Jan 1994

HAL is a multi-disciplinary open access archive for the deposit and dissemination of scientific research documents, whether they are published or not. The documents may come from teaching and research institutions in France or abroad, or from public or private research centers.
L'archive ouverte pluridisciplinaire HAL, est destinée au dépôt et à la diffusion de documents scientifiques de niveau recherche, publiés ou non, émanant des établissements d'enseignement et de recherche français ou étrangers, des laboratoires publics ou privés. 
la méthode des coups de dents (MAT : $5,9 \%$, NDF : $65 \%$, ADL: $35 \%$ ), ne pouvant expliquer l'attrait important des chèvres pour cet arbuste, des mesures de son utilisation digestive ont été effectuées sur 3 chèvres fistulées au niveau du rumen.

Huit séries de mesures échelonnées sur 2 ans ont porté sur : i) l'évolution journalière de 3 paramètres ruminaux ( $\mathrm{pH}, \mathrm{NH} 3, \mathrm{AGV}$ ) par des prélèvements de jus ruminal toutes les $2 \mathrm{~h}$ de $8 \mathrm{~h}$ à $20 \mathrm{~h}$; ii) l'évolution de la dégradabilité ruminale in sacco $(8 \mathrm{~h}, 24 \mathrm{~h}, 48 \mathrm{~h})$ de la bruyère arborescente en comparaison d'un témoin : la paille ammoniaquée.

La sortie sur parcours à $12 \mathrm{~h}$ induit, dans un bref délai : une chute du $\mathrm{pH}$ de $6,53 \pm 0,30$ à $5,91 \pm 0,20$; une chute du taux d'ammoniac avec des valeurs minimales atteignant $12 \mathrm{mg} / \mathrm{l}$, une augmentation rapide du taux d'AGV (59,9 \pm $5,0 \mathrm{mM} / \mathrm{l}$ à $85,2 \pm 4,0 \mathrm{mM} / \mathrm{l})$.

L'augmentation de l'activité fermentaire est plus liée à l'ingestion de substances solubles très rapidement métabolisées dans le rumen qu'à une modification de la flore ruminale sous l'effet de substances telles que les tannins. Dès l'entrée sur parc, les mesures de comportement ont montré que les chèvres effectuent un tri très important des organes les plus digestibles des ligneux. Les taux butyreux très faibles $(24,9 \pm 3,40)$, caractéristiques d'une activité amylolytique du rumen, confirment ces résultats.

La paille ammoniaquée, riche en fibres digestibles, présente une cinétique de dégradabilité de la matière sèche qui évolue de $26 \pm 4 \%$ à $56 \pm$ $12 \%$ entre $8 \mathrm{~h}$ et $48 \mathrm{~h}$, caractéristique d'une activité cellulolytique du rumen, lente et progressive, normale pour ce type d'aliments. En revanche, la bruyère arborescente, après une dégradation voisine à $8 \mathrm{~h}(29 \pm 5 \%)$, présente une courbe de dégradabilité qui s'infléchit pour n'atteindre que $39 \pm 5 \%$ à $48 \mathrm{~h}$. Seule les constituants non pariétaux de cet arbuste sont correctement valorisés par les chèvres.

Les résultats montrent que ce parcours ne doit pas être considéré comme une ressource riche en fibres, mais comme un apport en substances rapidement utilisables au niveau du rumen.

\section{Effects of ruminally infused niacin on digestibility and rumen fermentation in the cow. JF Ottou 1,2, M Doreau ${ }^{1}\left({ }^{1}\right.$ INRA- Theix, Laboratoire Sous-Nutrition des Rumi-}

nants, 63122 Saint-Genès-Champanelle, France; 2 IRZV, BP 1457, Yaoundé, Cameroon)

The aim of this study was to evaluate the influence of dietary niacin on nutrient digestibility, DM degradability and fermentation end products in the rumen.

Four multiparous Holstein cows in mid-lactation, fitted with ruminal cannulae were fed a maize silage and concentrate diet in ratio 80:20 (DM basis). Daily infusion in the rumen was either $0(\mathbf{C})$ or $6(\mathbf{N}) \mathrm{g}$ niacin in $100 \mathrm{ml}$ water in a $2 \times 2$ cross-over design. Each period lasted 4 weeks, at the end of which analyses were carried out for in vivo digestibility by total collection of faeces, in sacco DM disappearance of maize silage free of soluble constituents, and end products of ruminal digestion (VFA and $\mathrm{NH}_{3}$ ).

The mean DM intake was similar in the 2 treatments, 19.3 (SEM, 0.9) kg/d. In cows fed diets $\mathbf{N}$ and $\mathbf{C}$, digestibility coefficients (\%) were respectively, 70.5 and 69.8 (SEM, 0.9) for DM; 73.1 and 72.3 (SEM, 0.9) for organic matter; 53.9 and 49.3 (SEM, 2.0) for ADF; 55.6 and 52.3 (SEM, 1.7) for NDF. None of the trends to a higher digestibility with niacin supplement was significant $(P>$ $0.10)$. Total volatile fatty-acid content $(\mathrm{mM}) 2 \mathrm{~h}$ after feeding was 100.4 (N) and 94.9 (C) (SEM, 3.2). Niacin significantly increased $(P<0.05)$ the proportion of butyrate (13.9 vs $12.1 \%$; SEM, $0.7 \%)$, and non-significantly decreased $(P>0.10)$ the proportion of acetate and propionate. Rumen $\mathrm{NH}_{3}(\mathrm{mg} / \mathrm{dl}) 2 \mathrm{~h}$ after feeding was $197.9(\mathrm{~N})$ and 208.8 (C) (SEM, 5.8) $(P>0.10)$. In sacco DM disappearance (\%) was 20.0 and 18.1 (SEM, 1.3) after $6 \mathrm{~h}$ of incubation and 33.9 and 32.4 (SEM, 1.8) after $24 \mathrm{~h}$, for treatments $N$ and $C$ respectively. The niacin effect was not significant $(P>$ 0.10 ) for rumen $\mathrm{NH}_{3}$ and independent of sampling time for in sacco DM disappearance.

Current results indicate that in animals fed roughage and concentrates in the ratio $80: 20$ (DM basis), digestive and ruminal responses to niacin supplement are slight. This effect is lower compared to that in diets with higher levels of concentrates. It may be hypothesized that changes in rumen digestion when feeding highenergy diets are likely to induce an increased demand for niacin. 